Огляди літератури, оригінальні дослідження, погляд на проблему, випадок з практики, короткі повідомлення удК 616.98:579.834.114-074-053.2

DOI 10.11603/1811-2471.2021.v.i3.12505

\title{
АКТУАЛЬНІ ПИТАННЯ ХВОРОБИ ЛАЙМА У ДІТЕЙ
}

\section{๑С. О. Никитюк, С. І. Климнюк \\ Тернопільський національний медичний університет імені І. Я. Горбачевського МОЗ України}

РЕзЮМЕ. Хвороба Лайма має різні клінічні прояви, її слід виключити у всіх пацієнтів з укусом кліща. Хвороба Лайма викликається Borrelia burgdorferi senso lato, збудником гетерогенної групи, з якої три гени систематично асоціюються із хворобою Лайма: В. burgdorferi senso stricto, B. afzelii і В. garinii, і є ендемічною хворобою в Україні.

Ранні клінічні маркери Лайм-бореліозу та інші прогностичні фактори, що загрожують життю дитини, ускладнення бореліозної інфекції, все ще перебувають на початку активного дослідження вченими.

Висновки. Клініцисти, включаючи сімейних лікарів, ревматологів, імунологів та молекулярних кардіологів, повинні брати участь у розробці нових критеріїв, що включають клінічну картину та результати лабораторного дослідження.

КлючовІ СлОвА: діти; Лайм-бореліоз; діагностика; лікування; кліщі.

Вступ. Робота $є$ реалізацією українсько-польського проекту «Дослідження епідеміології, патогенезу, клініки та профілактики бореліозу" науково-дослідницьких проектів Європейського Союзу. Дослідження виконувалося в рамках науково-дослідної роботи «Моно- і змішані інфекції, що передаються кліщами, вдосконалення лікувальнодіагностичних технологій та заходів біобезпеки». Обстежували дітей, хворих на Лайм-бореліоз, асоційований з захворюваннями шкіри та опорно-рухової системи, а також іксодових кліщів, відібраних від пацієнтів.

Використовували клінічні (фізикальні, анкетування); епідеміологічні, спрямовані на 3 ланки епідеміологічного процесу; лабораторні методи дослідження: (ПЛР:ДНК основних видів Borrelia burgdorferi, Borrelia miyomatoi, Anaplasma phagocytophilum (в матеріалі від хворих, кліщах), визначення антитіл IgM та IgG методом ІФА до основних видів Borrelia burgdorferi в матеріалі від хворих: сироватці крові, лікворі, синовіальній рідинах; інтерлейкінів різних груп; антитіла IgM та IgG проти різних антигенів основних видів Borrelia burgdorferi методом Вестерн-Блот у матеріалі від хворих).

Основна частина. Як відомо, Лайм-бореліоз (ЛБ) - це багатосистемний розлад, викликаний Borrelia burgdorferi та іншими подібними бореліями, які переносяться кліщами. Хвороба Лайма, викликана Borrelia burgdorferi, $\epsilon$ найпоширенішою векторною хворобою в Західній Європі, особливо в її північному регіоні $[1,2,3,4,5,6,7]$. Довготривалі спостереження показали, що в Європі хвороба в більшості випадків викликається В. afzelii та B. garinii, [8] тоді як у США - В.burgdorferi [9]. Епідемічна ситуація по Лайм бореліозу напружена у Польші [7] та Україні [10, 11, 12]. На протязі 2020 р. захворюваність в Україні та Тернопільській області складала 10.62 та 20,05 на 100 тис. населення відповідно (Дані ЦГЗ) [13].
Симптоматична клінічна діагностика ЛБ на пізніх стадіях захворювання може бути складною, за умови відсутності в анамнезі мігруючої еритеми та факту укусу кліща, оскільки симптоми спільні 3 кількома іншими захворюваннями $[1,9,14-20]$.

Діти завжди $\epsilon$ найвразливішою групою населення, яка схильна до порушень у стані здоров'я, у тому числі й щодо укусу кліщів. У дітей трапляється відносно велика кількість випадків хвороби Лайма, ймовірно, через частіші укуси кліщів та зменшення уваги до профілактики хвороби Лайма.

У роботі використані бази даних про випадки Лайм-бореліозу (ЛБ) у дітей в Тернопільській області в 2017-2020рр. Хвороба Лайма - це полісимптомна хвороба, що передається іксодовими кліщами і характеризується поетапним перебігом та клінічним поліморфізмом. Більшість випадків хвороби Лайма трапляється внаслідок укусу інфікованих кліщів під час прогулянок, відпочинку та дозвілля. Тому діти, які живуть у лісистій місцевості або областях з підвищеною поширеністю борелізу, заражених векторними кліщами, ризикують отримати хворобу Лайма $[4,5]$.

Хвороба Лайма - природно-осередкова трансмісивна хвороба, яку викликають Borrelia burgdorferi, B. afzelii, B. garinii, B. spielmani i B. miyamotoi при укусі кліщів. у Євразії трансмісія борелій відбувається за допомогою Ixodes ricinus і тайгових кліщів Ixodes persulcatus, у США - чорноногого кліща Ixodes scapularis. Установлено, що деякі борелії (B. spielmanii, B. bissettii, B. valaisiana) спричиняють захворювання людини, але лише три з них (B. burgdorferi s.s, B. garinii and B.afzelii) широко визнані як збудники хвороб у людини [16, 17, 21-23]. у Європі найпоширенішими збудниками хвороби Лайма (або системного кліщового бореліозу, Лайм-бореліозу (ЛБ), $\in$ B. afzelii та B. garinii [24]. LB офіційно класифікується як особливо небезпечне інфекційне захворювання [26]. 
Огляди літератури, оригінальні дослідження, погляд на проблему, випадок з практики, короткі повідомлення

Захворюваність на ЛБ в Україні також неухильно зростає. Наприклад, за даними Центру громадського здоров'я МОЗ України [13, 25], у 2000 р. було зареєстровано лише 58 випадків ЛБ (0,12 на 100000 населення), а в 2018 р. уже було 5418 випадків (12,78 на 100000 населення). Тому за цей період захворюваність на ЛБ зросла у 93,4 раза [27]. Впродовж 2020 р. захворюваність в Україні та Тернопільській області складала 10,62 та 20,05 на 100 тис. населення відповідно (Дані ЦГЗ) (рис. 1).

Клінічні форми Лайм-бореліозу в дітей. Клінічна маніфестація хвороби Лайма на ранніх стадіях часто включає мігруючу еритему та ранньо поширену інфекцію (ураження множинною еритемою, параліч черепно-мозкових нервів - найчастіше VII, асептичний менінгіт або гостра неврологічна радикулопатія (параліч Белла, радикулоневрит, менінгіт) [27] з проявом лімфаденопатії [28, 29] або серця (атріовентрикулярна блокада, міоперикардит, панкардит) $[30,31]$. Ураження суглобів і біль - це симптоми, які направляють пацієнтів до ревматологів. Безпосередньо загрожує життю пацієнта, інфікованого B. burgdorfery, ураження нервової системи та серця, які можуть бути пов'язані 3 іншими симптомами, і не завжди симптоми, наприклад, міокардити, виходять на перший план від самого початку [29, 32].

Відомо, що хвороба тривалий час може перебігати безсимптомно, а згодом переходити у маніфестну форму з хронічним рецидивним або безперервно прогресуючим перебігом. Результати сучасних наукових досліджень щодо Лаймбореліозу суперечливі, оскільки ці порушення часто співіснують у клінічному аспекті i, як самостійно, так і в сукупності, враховуються при визна- ченні факторів порушення здоров'я людей, які постраждали внаслідок нападу кліщів [33-35]. У клінічній практиці описані випадки маскування для інших захворювань, наприклад, реакція гіперчутливості на укус кліща (виникає протягом 48 годин після укусу кліща, швидко зникає протягом 24-48 год), мультиформна еритема - алергічна реакція, дерматомікоз, кільцеподібна гранульома (Aucott J., Morrison B. et al., 2009) [5].

Частка пацієнтів із системними симптомами в США вища, ніж у Європі. У 30-50 \% випадків ураження збільшуються внаслідок раннього поширення B. burgdorferi [16].

Згідно з CDC [27], найпоширенішими симптомами кліщових захворювань $\epsilon$ :

- лихоманка / озноб: при всіх кліщових захворюваннях у пацієнтів може спостерігатися лихоманка різного ступеня;

- біль: симптоми захворювання включають головний біль, втому і біль у м'язах та суглобах. Ступінь тяжкості та тривалість цих симптомів можуть залежати від хвороби пацієнта та особистої переносимості.

Усі ознаки та симптоми захворювання, включаючи ураження шкіри, зазвичай спонтанно зникають приблизно через 1 місяць [22]. Епідеміологічні дослідження повідомляли про позитивні антитіла IgM та / або IgG проти збудника у 5-37 \% пацієнтів з однією ЕМ та в 22-89 \% з множинною EM, однак, незалежно від позитивності антитіл, лабораторні дослідження не показують ознаки запалення або будь-які інші аномалії [23]. На думку Т. Балмеллі, J. C. Piffaretti (1995), усі три генотипи видів борелій можуть викликати весь спектр клінічних проявів ль; $є$ дані, що B. afzelii частіше

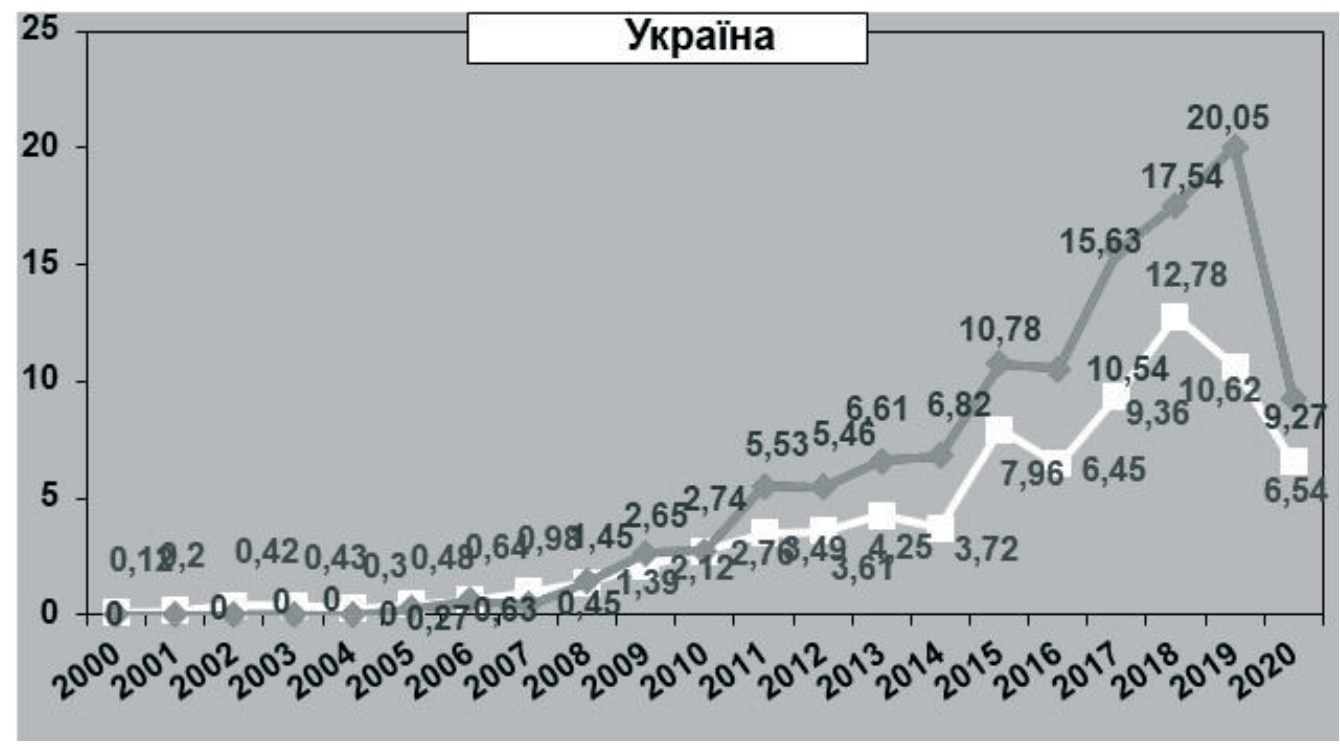

Рис. 1. Показники захворюваності на хворобу Лайма в Україні та області за 2000-2020 роки (на 100 тис. населення) (за даними ЦГЗ). 
Огляди літератури, оригінальні дослідження, погляд на проблему, випадок з практики, короткі повідомлення

асоціюється із шкірними проявами, B. garinii - 3 неврологічними симптомами, B. burgdorferi ss acoціюється переважно з артритом [36].

Клінічна картина перебігу хвороби Лайма, яку часто називають «великим імітатором» $[6,33$, $37,38]$, включає ранню локалізовану, ранню дисеміновану та пізню дисеміновану стадії. В ранньому періоді виділяють І стадію локальної інфекції, коли збудник після укусу кліща потрапляє в шкіру. Рання локалізована стадія хвороби починається через 3-30 днів після укусу кліща. При цьому в місці укусу кліща розвивається локалізована еритематозна кругла макула або папула, відома як erythema migrans (EM). Вона розширюється від кількох днів до тижнів, іноді з центральним очищенням, і має вигляд бичачого ока $[4,5]$. Поперечний діаметр ЕМ становить $\geq 5$ см [5]. Захворювання, викликані B. burgdorferii sensu stricto, як правило мають запальний характер [39] і частіше викликають поодинокі або множинні ЕМ, артрит і кардит. Вважають, що ЕМє найпоширенішим клінічним проявом хвороби Лайма і може бути маніфестацією шкірної інфекції, яка викликана саме B. burgdorferi [14]. ЕМ слід діагностувати і лікувати без попереднього виконання лабораторних аналізів. Така вимога діє у випадку множинних уражень. Розпізнавання ЕМ і невідкладний початок протимікробного лікування $є$ запорукою запобігання розвитку пізніх симптомів.

Неспецифічні симптоми зазвичай супроводжують специфічні ознаки, але майже ніколи не $\epsilon$ єдиним доказом хвороби Лайма [34]. Серологічне тестування для хвороби Лайма не повинно виконуватися у дітей без симптомів або ознак, що свідчать про хворобу Лайма, і правдоподібної географічної експозиції [25].

Клінічно у дітей з ЕМ можуть проявлятися грипоподібні симптоми, що включають втому, головний біль, лімфаденопатію [7], артралгію, міалгію, субфебрильну температуру та озноб $[5,40]$. У цій ситуації клініцисту доводиться враховувати сезон та можливість проживання чи перебування хворого в ендемічному щодо хвороби Лайма регіоні.

За відсутності лікування на ранній локалізованій стадії починається рання дисемінована стадія, яка виникає внаслідок інвазії спірохет у різні органи та тканини, поширюється на інші ділянки тіла і у 50 \% пацієнтів спричиняє пізні симптоми.

Вони можуть виникнути через кілька тижнів, місяців чи навіть років після появи МЕ на шкірі. Відсутність висипу не обов'язково свідчить про відсутність дисемінованого захворювання [41]. Пізня дисемінована стадія (III стадія) визначається персистуванням збудника інфекції в будь-якому органі чи тканині. На відміну від II стадії, для неї характерне вибіркове ураження якогось одного органа чи системи. Стадія пізнього розповсюдження триває місяцями і роками після укусу кліща та розвивається у 60 \% пацієнтів, які не отримували лікування [5].

У хворого можуть виникати періодичні напади артриту, а у 5 \% осіб продовжують розвиватися хронічні неврологічні симптоми.

Іноді стадійність перебігу хвороби може не спостерігатися зовсім, а в деяких випадках хвороба обмежується тільки I стадією або зразу дебютує одним із пізніх синдромів.

У ранньому періоді доцільно виділяти еритемну і безеритемну форми захворювання. Припускають, що B. miyamotoi викликають безеритемні форми захворювання людини $[9,14,40]$.

Це важливо пам'ятати при діагностиці, адже в такому випадку клінічна картина захворювання має певні особливості, які залежать від наявності чи відсутності еритеми в місці укусу кліща, що вказує на особливості взаємовідносин макро- і мікроорганізму.

На стадії дисемінації збудника виділяють провідні синдроми: лихоманковий, невритичний, менінгеальний, кардіальний, змішаний.

Інкубаційний період бореліозу коливається від 3 до 30 діб (частіше 7-10 діб), достовірність тривалості котрого залежить від точності встановлення факту укусу кліща.

Захворювання зазвичай починається підгостро, з появи болючості, свербежу, набряку і почервоніння у місці укусу кліща. Хворі скаржаться на помірний головний біль, загальну слабкість, нездужання, нудоту, відчуття скутості і порушення чутливості в ділянці укусу комахи. З'являється характерна еритема шкіри (спостерігається в 70 \% хворих). Температура тіла підвищується, частіше до $38^{\circ} \mathrm{C}$, іноді супроводжується ознобом. Період лихоманки триває 2-7 діб. Після зниження температури тіла іноді впродовж декількох діб відмічається субфебрильна температура.

Для першої стадії хвороби характерна поява мігруючої еритеми [33]. Лайма артрит (ЛА) характеризується запальним артритом, який зазвичай уражає великі суглоби, особливо колінні. Хоча артралгія може бути на будь-якій стадії хвороби Лайма, Лайм-артрит має об'єктивні докази суглобової пухлини, а також білих кров'яних клітин у зразках синовіальної рідини. Артрит може бути без історії попередніх стадій захворювання (в тому числі мігруючої еритеми) [35, 42].

Мігруюча еритема - основний клінічний прояв захворювання - з'являється через 3-32 дні як червона пляма або папула на місці укусу кліща. Ділянка почервоніння навколо місця укусу розширюється, відмежовується від неураженої шкіри яскраво-червоною облямівкою. В центрі ураження інтенсивність змін виражена менше. Розмі- 
Огляди літератури, оригінальні дослідження, погляд на проблему, випадок з практики, короткі повідомлення

ри еритеми можуть коливатися від 3 до 70 см, залежно від місця укусу, однак тяжкість перебігу захворювання не має зв'язку з їі розмірами. В місці початкового ураження іноді спостерігається інтенсивна еритема, з'являється везикула, а потім і некроз (первинний афект). Інтенсивність забарвлення ураженої шкіри рівномірно поширюється на всьому протязі. В межах зовнішньої межі можуть з'являтися декілька червоних кілець, центральна частина яких з часом блідне.

На місці, де була еритема, часто зберігаються посилена пігментація і лущення шкіри. У хворих, В яких не виникла EM, можуть спостерігатися лише грипоподібні симптоми $[5,16,43]$.

Педіатру доводиться враховувати сезон року та ендемічну зону, в якій проживає або тимчасово перебуває хворий, щоб мати можливість клінічно запідозрити хворобу Лайма.

Можлива поява й інших шкірних симптомів: висипання на обличчі, кропив'янка, перехідні точкові та дрібні кільцеподібні висипання, приєднується кон'юнктивіт. Еритему слід диференціювати з бешиховим запаленням, а при наявності первинного афекту і регіонарного лімфаденіту - 3 проявами кліщового висипного тифу і туляремії $[28,29,44]$.

Шкірні симптоми часто супроводжуються цефалгіями, ригідністю шийних м'язів, лихоманкою, ознобом, кашлем, мігруючими міалгіями й артралгіями, вираженою слабкістю і втомлюваністю. У дітей можуть спостерігатися генералізована лімфаденопатія, біль у горлі, сухий кашель, кон'юнктивіт, а у хлопчиків - набряк яєчок. Перші симптоми захворювання зазвичай послаблюються і самостійно повністю минають протягом декількох днів (тижнів), часто навіть без лікування. Лише 2 \% пацієнтів з ЛБ мають борелійну лімфоцитому (БЛ) [45]. Діагноз БЛ $\epsilon$ клінічним для пацієнтів із супутньою мігруючою еритемою (ЕМ). Пов'язані симптоми та клінічні дані, що вказують на дисемінований лБ, повідомляються у 82 \% та 14 \% дорослих пацієнтів із БЛ. Повідомляється про кардит у дитини з БЛ. Автори рекомендують проводити електрокардіограму (ЕКГ) кожній дитині з бореліальну лімфоцитому (БЛ) для скринінгу на діагностику ЛБ [46].

Бореліозний артрит і кардит частіше трапляються в США, тоді як неврологічні й пізні шкірні прояви частіше виявляють в Європі [47-49]. Діти частіше, ніж дорослі, мають лімфоцитоми (котрі виникають на вусі або соску) [50].

B. garinii викликає типову клінічну картину нейробореліозу (менінгорадикулярний біль без температури та легкої нудоти і блювання, лімфоцитарний плеоцитоз ліквору та високий рівень білка у лікворі), тоді як клінічні особливості, пов'язані з B. afzelii, менш специфічні $[8,51]$.
Згідно з класифікацією EFNS [52], нейробореліоз поділяють на ранній і пізній. Ранній нейробореліоз $\epsilon$ найпоширенішою клінічною формою дисемінованої інфекції, він виникає через 6 місяців після укусу, часто вже на стадії МЕ. У 5 \% продовжують розвиватися хронічні неврологічні симптоми. Нейробореліоз, на відміну від кліщового енцефаліту, має бактеріальне походження. Гострий нейробореліоз (НБ) може дебютувати руховими або сенсорними порушеннями, корінцевим больовим радикулярним синдромом, парестезіями [53]. Це може імітувати симптоми стиснення корінців спинного нерва. Останній потребує диференціювання з симптомом компресії спінальних корінців (пухлини, уроджені вади). При ранньому нейробореліозі неврологічна симптоматика виникає до 6 місяців після укусу кліща, при пізньому - через понад 6 місяців. Вона включає прояви периферичних та центральних уражень нервової системи (міоклонус, атаксію, запаморочення, моно- та поліневрит черепно-мозкових нервів, поперечний мієліт $[45,48,54]$.

Як зазначала Н. А. Пеньевская (2009), неврологічні симптоми, які характерні для ль, можуть включати лімфоцитарний менінгіт з ураженням черепно-мозкових нервів або полірадикулоневритом, невракситом чи енцефаломієлітом.

Неврологічні прояви нейробореліозу включають ураження $n$. facialis (VII), паралічі інших черепно-мозкових нервів, асептичний менінгіт і радикулоневропатію $[35,42,49,55,56]$. Менінгорадикулоневрит (синдром Баннварта) $\epsilon$ другим за поширеністю пізнім проявом хвороби Лайма в Європі. Його клінічними особливостями $є$ ураження черепно-мозкових нервів, корінцевий синдром, а також лімфомоноцитарний менінгіт із плеоцитозом та наявністю специфічних антитіл до B. burgdorferi в спинномозковій рідині. Параліч лицьового нерва був виявлений у 56 \% хворих дітей, часто в поєднанні з неспецифічними симптомами (цефалгії, астенічний синдром, помірні міалгії) [57]. Коли у хворого наявні неспецифічні симптоми, без проявів паралічу, можлива затримка етіологічної діагностики патологічного стану дитини. Проведені спостереження свідчать [58], що нейробореліоз часто має тривалі неспецифічні симптоми, що сповільнює й утруднює діагностику. Часто проводять повторні тривалі стаціонарні обстеження та госпіталізації дітей молодше 6 років без діагностики етіологічного чинника. У хворих із неспецифічними симптомами діагностика утруднена, порівняно з тими, у кого був виявлений параліч обличчя.

Незважаючи на велику кількість отриманих даних, слід наголосити, що спільні узгоджені критерії для діагностики нейробореліозу остаточно ще не розроблені. 
Огляди літератури, оригінальні дослідження, погляд на проблему, випадок з практики, короткі повідомлення

Діагностичні критерії Лайм-бореліозу від Європейської федерації неврологічних товариств (European federation of neurological Societies) y 2010 році включали 2 критерії з 3. Якщо третього критерію бракує, при повторенні тесту після 6 тижнів можливі позитивні результати. Запропонований двохетапний підхід до діагностики нейробореліозу. При тестуванні першого рівня визначають загальні IgM та IgG, а також їх співвідношення (IgM/ IgG) або окремі IgM та IgG за допомогою імуноферментного аналізу. Якщо у пацієнта був забраний ліквор, рекомендовано визначити індекс антитіл ліквору до сироваткових антитіл. Іноді можуть застосовувати імунофлуоресцентний тест і аналізи (IFA), вони включають імуноферментні аналізи, пов'язані з ферментами, флуоресцентні імунопроби та кількісні тести $[8,16,59]$. Вони діагностично чутливі, але мають лише близько 85 \% специфічності. Антитіла класу IgM часто бувають хибнопозитивними, причому їх можна виявити протягом багатьох років після перенесеного бореліозу [59]. Тому помилкові позитивні IFA щодо хвороби Лайма можуть виникати внаслідок наявності перехресно-реактивних антитіл, які з'являються при інших захворюваннях, включаючи групу кліщової плямистої гарячки (рикетсіоз), сифіліс, анаплазмоз, бактеріальний ендокардит, лептоспіроз, інфекційний мононуклеоз, деякі автоімунні захворювання, хвороби, які спричинені Helicobacter pyloriта Treponema denticola.

Підсумовуючи вищенаведене слід зазначити, що критеріями діагностики НБ $є$ наявність неврологічної симптоматики, інтратекальних імуноглобулінів до B. burgdorferi, плеоцитоз у цереброспінальній рідині. За наявності 2 із 3 перерахованих вище ознак можливе підтвердження нейробореліозу [52].

Лайм-артрит. Поширеність артриту у дітей віком до 18 років в Україні за даними 2020 року становить 62,3 на 100 000, первинна захворюваність 16,2 на 100 000. Лайм-артрит $\epsilon$ найпоширенішим проявом пізньої стадії лайм-бореліозу: він повідомляється в третині випадків $[10,27]$. Лайм-артрит вперше був описаний Steer та його співавторами в 1977 році у дітей та дорослих з олігоартикулярним артритом, що мешкали в районі Олд-Лайма, штат Коннектикут [42]. Ендемічними районами лаймського бореліозу є Північна Америка та Центральна Європа. Транзиторна артралгія проявляється як рання хвороба Лайма і розвивається через кілька тижнів після зараження [22]. Однак ранні стадії Лаймбореліозу можуть перебігати безсимптомно, і в цих випадках артрит може бути першим клінічним проявом захворювання [26]. Лайм-артрит зазвичай виникає через місяці і пов'язаний із уродженими та адаптивними імунними реакціями [23].
Лайм-артрит лікується антибіотиками протягом 2-4 тижнів, і в більшості випадків пацієнти одужують [22, 35]. Однак у невеликої кількості пацієнтів синовіт може зберігатися від місяців до кількох років, навіть після 1-2 місяців лікування антибіотиками, і є резистентним до антибіотиків (або повільно розсмоктуючим) лайм-артритом $[36,58]$.

У Сполучених Штатах Америки найпоширенішим проявом пізньої хвороби Лайма (ЛД) є переривчастий або хронічний моно- або олігоартрит, особливо, що вражає коліно. Лайм-артрит (ЛА) зазвичай можна запобігти шляхом раннього лікування гострого ЛБ $[35,42,58]$. Практично всі неліковані пацієнти з ЛОС мають високий рівень антитіл до імуноглобуліну сироватки G, а іноді і низький рівень антитіл імуноглобуліну $M$ до Borrelia burgdorferi (Bb) за допомогою ІФА та вестерн-блоту. Ці відповіді можуть зберігатися протягом багатьох років після лікування антибіотиками, і тому серологічні результати не точно розрізняють активну або минулу інфекцію [35].

Більшість пацієнтів з ЛА добре реагують на стандартні курси лікування антибіотиками, але невеликий відсоток мають стійкий синовіїт коліна, в деяких випадках, можливо, пов'язані з запуском автоімунного процесу. Інші пацієнти розвивають синдром дифузної артралгії, міалгії, втоми та суб'єктивних когнітивних труднощів під час або незабаром після ЛД, який зберігається, незважаючи на лікування антибіотиками. Пацієнти з цим пост-лікуванням, синдромом пост-лД, нещодавно були вивчені в плацебо-контрольованому подвійному сліпому випробуванні антибіотиків. Не було виявлено різниці в чутливості цих пацієнтів до 3-місячного курсу антибіотика, порівняно з лікуванням плацебо.

Разом з тим, при лайм-артриті, навіть без специфічної терапії, початкове число пацієнтів, схильних до артритичних атак, щорічно зменшується на 10-20\%, а через 5 років атак артриту зазнає вже мало хто. Тому вважають, що в кінцевому підсумку імунні механізми елімінують B. burgdorferi s.s. з суглоба. Однак у шкірному покриві B. afzelii, наприклад, може персистувати впродовж десятиліть, і при цьому розвивається хронічний атрофічний акродерматит, що свідчить про неефективність локальної внутрішньошкірної імунної відповіді. При ІКБ виявлена залежність між характером ураження нервової системи, а також ймовірністю розвитку артриту, що складно піддається лікуванню антибіотиками, і HLA-статусом людини $[42,58]$.

Клінічні характеристики дітей із лаймартритом змінюються залежно від віку. У 10 \% дорослих з лайм-артритом розвивається хронічний 
Огляди літератури, оригінальні дослідження, погляд на проблему, випадок з практики, короткі повідомлення

артрит. У дітей з лайм-артритом хронічний артрит трапляється рідше [22]. У літературі є суперечки щодо того, чи може борелійна інфекція викликати неспецифічні симптоми [23]. Ці неспецифічні симптоми можуть складатися з втоми, болю в кінцівках та нейрокогнітивних проблем. У нашому дослідженні порушення сну були виявлені у $21 \%$, проблеми з увагою - у 3 \%, ангіна - у 4,7 \%, кашель - у 5,4 \% дітей.

Больовий синдром у суглобах часом буває нестерпним, не відповідає на дію нестероїдних протизапальних препаратів. Хворий шукає холодне місце, інколи занурює у воду і тримає там кінцівку. Часом такі особи звертаються до невролога $з$ корінцевим болем. Стадія пізнього поширення триває місяцями або роками після укусу кліща i виникає у 60 \% пацієнтів, які не отримували лікування. У таких хворих можуть виникати періодичні напади артриту [9].

Більшість випадків лайм-кардиту клінічно безсимптомні. Якщо вони симптоматичні, типовими можуть бути скарги на втому, задишку, серцебиття, непритомність, синкопе та біль у грудях [10].

Інші серйозні та навіть смертельні ускладнення серця включають аритмію серця, міокардит, серцеву недостатність та раптову зупинку серця [30]. Рання хвороба Лайма, визначена як ознаки та симптоми, що тривають менше 6 місяців після укусу кліща, становить більшість випадків (95\%). У клінічній практиці пацієнти досить часто звертаються до ревматолога через артралгії або навіть артрит в ході бореліозу, і серцево-судинні симптоми не потрібно спочатку помічати, якщо вони не мають чіткого клінічного прояву.

У Європі лише 0,3-4 \% усіх випадків бореліозу проявляється міокардитом [60]. Лайм-кардит виникає, коли B. burgdorfery потрапляє безпосередньо в тканини серця [23], що може спричинити порушення провідності. Лаймський кардит може спричинити непритомність, задишку, серцебиття або біль у грудях. Найнебезпечнішим ускладненням провідних порушень $є$ повна атріовентрикулярна блокада серця. Його корекція вимагає використання кардіостимулятора. Інші серйозні та навіть смертельні ускладнення включають серцеву аритмію, міокардит, серцеву недостатність та раптову зупинку серця $[30,31]$. Ранній лаймкардит, що визначається як ознаки та симптоми, що тривають менше 6 місяців після укусу кліща, становить переважну більшість випадків (95 \%) [36]. Ураження міокарда проявляється різними симптомами, починаючи з болю у грудях та серцебиттям, зв'язком із транзиторними змінами на ЕКГ до небезпечних для життя кардіогенним шоком та шлуночковою аритмією $[30,61]$. у більшості випадків клінічний прояв міокардиту може бути проілюстрований трьома основними проявами: 1) гостра серцева недостатність, 2) аритмія та 3) біль у грудях [62].

Кардіальні симптоми не типові (<10\% пацієнтів) і рідко призводять до смерті пацієнта [63].

Пацієнти з Лайм-кардитом, як правило, відчувають подібні до грипу симптоми, такі як лихоманка та втома $[30,31]$. Проте в літературі описані такі грізні випадки [12]. 17-річний підліток, який протягом 3 тижнів страждав від грипоподібних симптомів, а потім помер від лайм-кардиту.

Можуть траплятися шкірні прояви захворювання, зокрема мігруюча еритема $[1,30,64]$.

«Хронічний Лайм» $є$ суперечливим терміном, що описує тривалі неспецифічні скарги, які належать до ЛБ [65].

Важливо, щоб дітей із підозрою на лБ у обстежував педіатр із досвідом діагностики ЛБ. Це допомагає адекватно встановити або виключити діагноз ЛБ, потенційно запобігає недостатньому або надмірному лікуванню антибіотиками та може допомогти зменшити масштаби соціальних проблем ЛБ [66].

Відрізнити лайм-менінгіт від ентеровірусного менінгіту складно, оскільки обидва вони трапляються переважно в серпні та на початку осені. Але ця відмінність $\epsilon$ клінічно важливою, оскільки лише пацієнти з лайм-менінгітом потребують парентеральної антибіотикотерапії. Результати діагностичного тесту на патогени доступні не відразу $[30,31,64]$. Попередня диференціація хвороби Лайма від ентеровірусного менінгіту може керуватися рішеннями щодо клінічного лікування в умовах невідкладної допомоги. $€$ дослідження, що визначають клінічні та лабораторні особливості, які можуть допомогти клініцистам диференціювати пацієнтів із лайм-менінгітом від тих, хто страждає ентеровірусними менінгітами [67].

Методи лікування ЛБ у дітей. Хворих можна лікувати емпірично, але антимікробна терапія може знизити імунну відповідь, що призведе до помилково негативних результатів серологічних тестів.

Доведена лікувальна ефективність доксацикліну (юнідоксу), азитроміцину та деяких інших антибактеріальних препаратів [68]. З'явилися науково-популярні статті і телепередачі для населення, які висвітлюють способи профілактики захворювання. Поліпшилась специфічна діагностика хвороби Лайма, збільшилася кількість лабораторій, які використовують молекулярно-мікробіологічні методи і обстеження. 3'явились перші публікації про результати економічного аналізу, втрати від захворювання на різні клінічні форми 
Огляди літератури, оригінальні дослідження, погляд на проблему, випадок з практики, короткі повідомлення

Лайм-бореліозу та економічне обґрунтування доцільності проведення лікувально-діагностичних заходів.

Так, діти з лайм-менінгітом у Сполучених Штатах зазвичай отримують 2-4 тижні парентеральні антибіотики, найчастіше - цефтріаксон [68]. Діти, які лікуються від лайм-менінгіту, можуть мати ускладнення. Попередні дослідження лікування дорослих із лайм-менінгітом повідомляли про ускладнення лікування. У 2 рандомізованих контрольованих дослідженнях дорослих із лаймським менінгітом, що порівнювали цефтріаксон з доксицикліном, у 4 із 77 дорослих, рандомізованих на лікування цефтріаксоном (5 \%), було побічних явищ, що призвели до припинення цієї терапії [50]. Як відомо, лікування паралічу обличчя займає більше часу, але в іншому випадку тип або тривалість симптомів до лікування не мали статистично значущого впливу на результат. Відрізнити лайм-менінгіт від ентеровірусного менінгіту складно, оскільки обидва вони трапляються переважно в сумі та на початку осені. Ця відмінність $є$ клінічно важливою, оскільки лише пацієнти з лайм-менінгітом потребують парентеральної антибіотикотерапії. Результати діагностичного тесту на патогени доступні не відразу. Таким чином, попередня диференціація Лайма від ентеровірусного менінгіту може керуватися рішеннями щодо клінічного лікування в умовах невідкладної допомоги. Є дослідження, що визначають клінічні та лабораторні особливості, які можуть допомогти клініцистам диференціювати пацієнтів із лайм-менінгітом $[6,54]$ від тих, хто страждає ентеровірусними менінгітами. Хоча швидкі діагностичні тести за допомогою ПлР можуть полегшити ранню діагностику ентеровірусного менінгіту, небагато лікарів проводять ці тести. Рання диференціація лайм-менінгіту від ентеровірусного менінгіту дозволить швидко почати прийом антибіотиків у пацієнтів із передбачуваним лайм-менінгітом та зменшити непотрібне тестування у тих, які навряд чи мають лайм-менінгіт. Автори розширили ці спостереження, порівнюючи пацієнтів із лаймським менінгітом та пацієнтів з ентеровірусним менінгітом, підтвердженим ПлР цереброспінальної рідини [67].

Усі діти з паралічем обличчя звернулись за медичною допомогою протягом 2 днів після початку [69]. У трьох дітей розвинувся нейробореліоз, незважаючи на попереднє пероральне лікування антибіотиками при мігруючій еритемі. Діти із симптомами протягом 2 тижнів були молодшими (медіана 6,0 проти 7,7 років) і серопозитивні в лікворі (CSF) рідше, ніж ті, що мають більшу тривалість (69 \% проти 88 \%). В іншому випадку між групами не було відмінностей щодо віку чи результатів ліквору. Стан усіх дітей помітно покращився протягом декількох днів після терапії [69, 70]. Наприкінці лікування $58 \%$ дітей не мали симптомів, як це було у 92 \% пацієнтів через 2 місяці. Через 6 місяців після хвороби всі діти були безсимптомними і вважалися вилікуваними. Бета-лактами, такі як бензилпеніцилін, цефотаксим та цефтріаксон, $є$ ефективним методом лікування нейробореліозу. Пероральний доксициклін був таким же ефективним, як і внутрішньовенні беталактами для лікування, та профілактики пізніх проявів гострої дисемінованої хвороби Лайма.

Порівняння азитроміцину та амоксициліну для лікування дітей з одиночною ЕМ виявило зіставну ефективність та несприятливі ефекти лікування [71].

Погіршення місцевих та/або системних ознак та симптомів на початку терапії антибіотиками (реакція Джаріша Герксгеймера) було описано в роботах [72-74].

Висновки. Хвороба Лайма - це ендемічне захворювання, що набуває характеру пандемії, число дітей, хворих на Лайм-бореліоз, зростає. Імунітет проти Borrelia burgdorferi не $\epsilon$ довічним і у частини людей, що перенесли ЛБ, через деякий час можливе повторне зараження.

\section{ЛІТЕРАТУРА}

1. Serum reactivity against Borrelia burgdorferi OspA in patients with rheumatoid arthritis / Y. F. Hsieh, H. W. Liu, T. C. Hsu [et al.] // Clin. Vaccine Immunol. - 2007. Vol. 14 (11). - P. 1437-1441.

2. Lyme borreliosis in southern United Kingdom and a case for a new syndrome, chronic arthropod-borne neuropathy / M. S. Dryden, K. Saeed, S. Ogborn, P. Swales // Epidemiol. Infect. - 2015. - Vol. 143 (3). - P. 561-572.

3. Epidemiological surveillance of Lyme borreliosis in Bavaria, Germany, 2013-2020 / M. M. Böhmer, K. Ens, S. Böhm [et al.] // Microorganisms. - 2021. - Vol. 9 (9). P. 1872.

4. Stanek G. The expanding Lyme Borrelia complexclinical significance of genomic species? / G. Stanek, M. Reiter // Clin. Microbiol. Infect. - 2011. - Vol. 17 (4). P. 487-493.

5. Strle F. Clinical manifestations and diagnosis of Lyme borreliosis / F. Strle, G. Stanek // Curr. Probl. Dermatol. - 2009. - Vol. 37. - P. 51-110.

6. Шкільна М. І. Лайм-бореліоз у працівників лісових господарств Тернопільської області / М. І. Шкільна // Інфекційні хвороби. - 2016. - № 1 (83). - С. 36-40.

7. Випадок гострого нейробореліозу у хлопчика шкільного віку / С. О. Никитюк, М. М. Костик, С. В. Кізан, 
Огляди літератури, оригінальні дослідження, погляд на проблему, випадок з практики, короткі повідомлення

3. Я. Борис // Актуальна інфектологія. - 2018. - Т. 6, № 4. - C. 53-54.

8. Serodiagnosis of Lyme borreliosis by Borrelia burgdorferi sensu stricto, B. garinii, and B. afzelii western blots (immunoblots) / G. L. Norman, J. M. Antig, G. Bigaignon, W. R. Hogrefe // J. Clin. Microbiol. - 1996. Vol. 34 (7). - P. 1732-1738.

9. Centers for disease control and prevention. Reported cases of Lyme disease by year, United States, 20022011. - 2012. - URL: http://www.cdc.gov/lyme/stats/ chartstables/casesbyyear.html.

10. Частота виявлення борелій і анаплазми у кліщів, вилучених від мешканців Тернопільської області / М. А. Андрейчин, М.І.Шкільна, С. О. Никитюк [та ін.] // Епідеміологічні та клінічні ускладнення інфекційних і паразитарних хвороб у сучасних умовах : тези Всеукр. наук.-практ. конф. інфекціоністів і пленуму ГО ВАІ, 5-6 жовтня 2017 р., Житомир. - Тернопіль : Укрмедкнига, 2017. - С. 9-11.

11. Nykytyuk S. Clinical and immunological status of children with Lyme disease / S. Nykytyuk, S. Klymnyuk // Health Problems of Civilization. - 2021. DOI: 10.5114/ hpc.2021.108379.

12. Lyme disease: a case report of a 17-year-old male with fatal Lyme carditis / E. C. Yoon, E. Vail, G. Kleinman [et al.] // Cardiovasc. Pathol. - 2015. - Vol. 24 (5). - P. 317-321.

13. Центр громадського здоров'я України | МОЗ (phc.org.ua) [Електронний ресурс]. - Режим доступу: https://phc.org.ua.

14. Steere A. C. Lyme disease / A. C. Steere // N. Engl. J. Med. - 2001. - Vol. 345 (2). - P. 115-125. DOI: 10.1056/ nejm200107123450207.

15. Philip S. S. Current medical diagnosis and treatment / S. S. Philip // Spirochetal Infections. - New York: McGraw-Hill, 2013. - URL : http://www.accessmedicine.com. eres.library.manoa.hawaii.edu/content.aspx?aID=18802\& searchStr=lyme+disease.

16. Caulfield A. J. Lyme disease coinfections in the United States / A. J. Caulfield, B. S. Pritt // Clin. Lab. Med. 2015. - Vol. 35 (4). - P. 827-846.

17. Wilking $\mathrm{H}$. Trends in surveillance data of human Lyme borreliosis from six federal states in eastern Germany / H. Wilking, K. Stark // Ticks Tick Borne Dis. - 2014. Vol. 5 (3). - P. 219-224.

18. Disease-specific diagnosis of co-infecting tick-borne zoonoses: Babesiosis, human granulocytic ehrlichiosis, and Lyme disease / P. J. Krause, K. McKay, C. A. Thompson [et al.] // Clin. Infect. Dis. - 2002. - Vol. 34 (9). - P. 1184-1191.

19. Borrelia miyamatoi infection in nature and in humans / P. J. Krause, D. Fish, S. Narasimhan, A. G. Barbour // Clin. Microbiol. Infect. - 2015. - Vol. 21 (17). - P. 631-639.

20. Diagnosing borreliosis / S. J. Cutler, N. Rudenko, M. Golovchenko [et al.] // Vector-Borne Zoonotic Dis. 2017. - Vol. 17 (1). - P. 2-11.

21. Nyman D. Lyme borreliosis (LB) / D. Nyman, P. Wahlberg // EBM Guidelines. [Electronic resource]. 2017. - URL: https://www.ebmguidelines.com/dtk/ebmaz/ avaa?p_artikkeli=ebm00031.

22. Steer A. C. Lyme borreliosis / A. C. Steer // Harrison's infectious diseases / D. L. Casper \& A. S. Fauci eds. 17th edn. - The McGraw-Hill Companies. - New York, 2010. - P. 670-676.
23. Проблемы серологической диагностики иксодового клещевого боррелиоза у детей / Е. А. Мурина, О. В. Голева, 3. А. Осипова, А. Л. Мукомолова // Лаборатория ЛПУ. Спецвыпуск. - 2018. - № 13. - С. 38-40. - Peжим доступа: http://www.poliklin.ru/imagearticle/ 20184(1)/38.pdf.

24. Lyme borreliosis / G. Stanek, G. P. Wormser, J. Gray, F. Strle // Lancet. - 2012. - Vol. 379 (9814). - P. 461-473.

25. Prevention of tick bites and protection against tick-borne diseases in south-eastern Poland / K. Bartosik, T. Kubrak, T. Olszewski [et al.] // Ann. Agric. Environ. Med. 2008. - Vol. 15 (2). - P. 181-185.

26. Перелік особливо небезпечних, небезпечних інфекційних та паразитарних хвороб людини та носіїв збудників цих хвороб: наказ МОЗ України від 19.07.1995 p. № 133.

27. Centers for Disease Control and Prevention. Lyme disease (Borrelia burgdorferi): 2017 case definition. - URL: https://wwwn.cdc.gov/nndss/conditions/ lyme-disease/ case-definition/2017.

28. Lyme borreliosis: Clinical case definitions for diagnosis and management in Europe / G. Stanek, V. Fingerle, K. P. Hunfeld [et al.] // Clin. Microbiol. Infect. - 2011. Vol. 17 (1). - P. 69-79.

29. Інфекційні хвороби: енциклопедичний довідник / за ред. Крамарьова С. О., Голубовської О. А. - 2-е вид., переробл. і допов. - К. : ТОВ «Гармонія», 2019. 712 c.

30. Sigal L. H. Early disseminated Lyme disease: cardiac manifestations / L. H. Sigal // Am. J. Med. - 1995. Vol. 98 (4A). - P. 25S-28S; discussion 28S-29S. DOI: 10.1016/S0002-9343(99)80041-2.

31. Иммунохимический анализ рекомбинантногохимерного полипептида OspC [gar+afz] изолятов b. garini и b. afzelli / В. С. Караваев, Е. С. Олейникова, М. Ш. Азаев, А. Б. Беклемишев // Журнал микробиологии, эпидемиологии и иммунобиологии. - 2016. - № 3.C. 37-44.

32. Sjögren's syndrome and lymphadenopathy unraveling the diagnosis of Lyme diseas / S. Smiyan, I. Galaychuk, I. Zhulkevych [et al.] // Reumatologia. - 2019. Vol. 57 (1). - P. 59-62. DOI: https://doi.org/10.5114/reum. 2019.83242.

33. Lyme neuroborreliosis epidemiology in Sweden 2010 to 2014: clinical microbiology laboratories are a better data source than the hospital discharge diagnosis register separator commenting unavailable / V. Dahl, K. T. Wisell, C. G. Giske [et al.] // Euro. Surveill. - 2019. - Vol. 24 (20). DOI: 10.2807/1560-7917.ES.2019.24.20.1800453.

34. [Electronic resource]. - URL : https://guidelines. moz.gov.ua/documents/2959.

35. Bacon R. M. Centers for Disease Control and Prevention (CDC) Surveillance for Lyme disease-United States, 1992-2006 / R. M. Bacon, K. J. Kugeler, P. S. Mead // MMWR Surveill Summ. - 2008. - Vol. 57 (10). - P. 1-9.

36. Nyman D. Lyme borreliosis (LB) EBM Guidelines / D. Nyman, P. Wahlberg. [Electronic resource]. - 2017. URL: https://www.ebm-guidelines.com/dtk/ebmaz/avaa?p _artikkeli=ebm00031.

37. Prospective study of coinfection in patients with erythema migrans / A. C. Steere, G. McHugh, C. Suarez [et al.] // Clin. Infect. Dis. - 2003. - Vol. 36 (8). - P. 1078-1081. 
Огляди літератури, оригінальні дослідження, погляд на проблему, випадок з практики, короткі повідомлення

38. Weber K. Aspects of Lyme borreliosis in Europe / K. Weber // Eur. J. Clin. Microbiol. Infect. Dis. - 2001. Vol. 20 (1). - P. 6-13.

39. Централизованная информационная система по инфекционным заболеваниям Европейского регионарного бюро ВОЗ [Электронный ресурс]. - 2019. - Режим доступа: http://www.euro.who.int/en/search?q=lyme +disease+in+ukraine.

40. Dynamics of spirochetemia and early PCR detection of Borrelia miyamotoi / L. Karan, M. Makenov, N. Kolyasnikova [et al.] // Emerg. Infect. Dis. - 2018. - Vol. 24 (5). P. 860-867. DOI: 10.3201/eid2405.170829.

41. Климнюк С. І. Сучасні уявлення про гранулоцитарний анаплазмоз людини / С. І. Климнюк, Л. Б. Романюк, М. І. Шкільна // Інфекційні хвороби. - 2017. - № 3. C. 4-9.

42. Steere A. C. The emergence of Lyme disease / A. C. Steere, J. Coburn, L. Glickstein // J. Clin. Invest. -2004. Vol. 113 (8). - P. 1093-1101.

43. Клинико-эпидемиологический анализ результатов выявления антител к различным видам риккетсий у больных с подозрением на клещевую нейроинфекцию в северных районах Омской области / Н. А. Пеньевская, Н. В. Рудаков, Н. В. Абрамова [и др.] // Сибирский медицинский журнал. - 2009. - № 8. - С. 48-53.

44. Logigian E. L. Neurologic manifestations of Lyme disease / E. L. Logigian, R. F. Kaplan, A. C. Steere // N. Engl. J. Med. - 1990. - Vol. 323 (21). - P. 1438.

45. Nau R. Lyme disease: current state of knowledge / R. Nau, H. J. Christen, H. Eiffert // Dtsch. Arztebl. Int. 2009. - Vol. 106 (5). - P. 72-81.

46. Микст-инфекция: клещевой энцефалит и гранулоцитарний анаплазмоз человека / С. А. Дракина, Л. А. Анисько, В. В. Щерба [и др.] // Клиническая инфектология и паразитология. - 2018. - № 1. - С. 21-26.

47. Halperin J. J. Nervous system Lyme disease / J. J. Halperin // J. R. Coll. Physicians Edinb. - 2010. Vol. 40 (3). - P. 248-255.

48. Neuroborreliosis in Swedish children: a population-based study on incidence and clinical characteristics / L. Södermark, V. Sigurdsson, W. Näs [et al.] // Pediatr. Infect. Dis. J. - 2017. - Vol. 36 (11). - P. 1052-1056. DOI: $10.1097 /$ INF.0000000000001653.

49. EFNS guidelines on the diagnosis and managementof European Lyme neuroborreliosis / A. Mygland, U. Ljostad, V. Fingerle [et al.] // Eur. J. Neurology. - 2010. Vol. 17. - P. 8-16.

50. Remiker A. A painless erythematous swelling of the external ear as a manifestation of Lyme disease / A. Remiker, D. Haslam, T. A. Kalfa // J. Med. Case Rep. - 2020. Vol. 14 (48). - P. 48. DOI: 10.1186/s13256-020-02377-x.

51. Dressler F. Antibody responses to the three genomic groups of Borrelia burgdorferi in European Lyme borreliosis / F. Dressler, R. Ackermann, A. C. Steere // J. Infect. Dis. - 1994. - Vol. 169 (2). - P. 313-318.

52. Laboratory diagnosis of Lyme neuroborreliosis: acomparison of three CSF anti-Borrelia antibody assays / A. J. Henningsson, M. Christiansson, I. Tjernberg, S. Löfgren // Eur. J. Clin. Microbial Infect. Dis. - 2014. Vol. 33 (5). - P. 797-803.

53. Бореліозна лімфаденопатія у практиці онколога (клінічні спостереження) / І. И. Галайчук, І.В.Жулкевич,
С. І. Сміян [та ін.] // Онкология. -2019. -Т. 21, № 3. -С. 250253. DOI: 10.32471/oncology.2663-7928.t-21-3- 2019-7896.

54. Лобзин Ю. В. Рекомендации для врачей / Ю. В. Лобзин, А. Г. Рахманова, В. С. Антонов. - СПб., 2000. -33 C.

55. Волоха А. П. Хвороба Лайма (кліщовий бореліоз) / А. П. Волоха // Інфекційні хвороби у дітей / за ред. Л. І. Чернишової. - К. : ВСВ «Медицина», 2016. С. $703-712$.

56. Lyme arthritis: an epidemic of oligoarticular arthritis in children and adults in three Connecticut communities / A. C. Steere, S. E. Malawista, D. R. Snydman [et al.] // Arthritis Rheum. - 1977. - Vol. 20 (1). - P. 7-17.

57. Steere A. C. Therapy for Lyme arthritis: strategies for the treatment of antibiotic-refractory arthritis / A. C. Steere, S. M. Angelis // Arthritis Rheum. 2006. Vol. 54 (10). - P. 3079-3086.

58. Lyme borreliosis / G. Stanek, G. P. Wormser, J. Gray, F. Strle // Lancet. - 2012. - Vol. 379 (9814). - P. 461-473.

59. Arvikar S. L. Diagnosis and treatment of Lyme arthritis / S. L. Arvikar, A. C. Steere // Infect. Dis. Clin. North. Am. - 2015. - Vol. 29 (2). - P. 269-280. DOI: 10.1016/j. idc.2015.02.004

60. Wormser G. P. Borrelia burgdorferi genotype predicts the capacity for hematogenous dissemination during early lyme disease / G. P. Wormser D. Brisson, D. Liveris // J. Infect. Dis. - 2008. - Vol. 198 (9). - P. 1358-1364.

61. Current state of knowledge on aetiology, diagnosis, management,and therapy of myocarditis: a position statement of the European Society of Cardiology Working Group on Myocardial and Pericardial Disease / A. L. Caforio, S. Pankuweit, E. Arbustini [et al.] // Eur. Heart J. 2013. - Vol. 34 (33). - P. 2634-2648.

62. Incidence of clinician-diagnosed Lyme disease, United States, 2005-2010 / C. A. Nelson, S. Saha, K. J. Kugeler [et al.] // Emerging Infect. Dis. - 2015. - Vol. 21 (9). P. 1625-1631.

63. Yeung C. Diagnosis and treatment of Lyme carditis: JACC review topic of the week / C. Yeung, A. Baranchuk // J. Am. Coll. Cardiol. - 2019. - Vol. 73 (6). - P. 717-726.

64. Conduction riddles of Lyme carditis: a case series / E. Torbey, N. Nalluri, K. Boutros [et al.] // J. Innov. Card. Rhythm. Manag. - 2015. - Vol. 6 (5). - P. 2004-2007.

65. Nassar-Sheikh Rashid A. Lyme borreliosis in children: a tertiary referral hospital-based retrospective analysis / A. Nassar-Sheikh Rashid, M. Boele van Hensbroek, M. Kolader [et al.] // Pediatr. Infect. Dis. J. - 2018. Vol. 37 (2). - P. e45-e47.

66. Early differentiation of Lyme from enteroviral meningitis / S. S. Shah, T. E. Zaoutis, J. Turnquist [et al.] // Pediatr. Infect. Dis. J. - 2005. - Vol. 24 (6). - P. 542-545.

67. Treatment complications in children with lyme meningitis / A. D. Thompson, K. A. Cohn, S. S. Shah [et al.] // Pediatr. Infect. Dis. J. - 2012. - Vol. 31 (10). - P. 1032-1035.

68. Cruickshank M. Lyme disease: summary of NICE guidance / M. Cruickshank, N. O'Flynn, S. N. Faust // Br. Med. J.-2018. - Vol. 361. -P. k1261. DOI: https://doi.org/10.1136/ bmj.k1261.

69. Prevalence of lyme meningitis in children with aseptic meningitis in a lyme disease-endemic region / A. C. Garro, M. S. Rutman, K. Simonsen [et al.] // Pediatr. Infect. Dis. J. - 2011. - Vol. 30 (11). - P. 990-992. 
Огляди літератури, оригінальні дослідження, погляд на проблему, випадок з практики, короткі повідомлення

70. Paediatric facial paralysis caused by Lyme borreliosis: a prospective and retrospective analysis / M. Peltomaa, H. Saxen, I. Seppälä [et al.] // Scand. J. Infect. Dis. 1998. - Vol. 30 (3). - P. 269-275.

71. The Jarisch-Herxheimer reaction associated with doxycycline in a patient with Lyme arthritis / S. Nykytyuk, O. Boyarchuk, S. Klymnyuk, S. Levenets // Reumatologia. 2020. - Vol. 58 (5). - P. 335-338.

\section{REFERENCES}

1. Hsieh, Y.F., Liu, H.W., Hsu, T.C., Wei, J.C., Shih, C.M., Krause, P.J., \& Tsay, G.J. (2007). Serum reactivity against Borrelia burgdorferi OspA in patients with rheumatoid arthritis. Clin. Vaccine Immunol., 14 (11), 1437-1441. DOI: 10.1128/CVI.00151-07.

2. Dryden, M.S., Saeed, K., Ogborn, S., \& Swales, P. (2015). Lyme borreliosis in southern United Kingdom and a case for a new syndrome, chronic arthropod-borne neuropathy. Epidemiol. Infect., 143 (3), 561-572. DOI: $10.1017 / \mathrm{S} 0950268814001071$.

3. Böhmer, M.M., Ens, K., Böhm, S., Heinzinger, S., \& Fingerle, V. (2021). Epidemiological surveillance of Lyme borreliosis in Bavaria, Germany, 2013-2020. Microorganisms, 9 (9), 1872. DOI: 10.3390/microorganisms9091872.

4. Stanek, G., \& Reiter, M. (2011). The expanding Lyme Borrelia complex - clinical significance of genomic species? Clin. Microbiol. Infect., 17 (4), 487-493. DOI: 10.1111/ j.1469-0691.2011.03492.x.

5. Strle, F., \& Stanek, G. (2009). Clinical manifestations and diagnosis of Lyme borreliosis. Curr. Probl. Dermatol., 37, 51-110. DOI: 10.1159/000213070.

6. Shkilna, M.I. (2016). Laym-borelioz u pratsivnykiv lisovykh hospodarstv Ternopilskoi oblasti [Lyme borreliosis in forestry workers of Ternopil region]. Infektsiini khvoroby - Infect. Dis., 1 (83), 36-40. DOI: https://doi. org/10.11603/1681-2727.2016.1.5957 [in Ukrainian].

7. Nykytyuk, S.O., Kostyk, M.M., Kizan, S.V., \& Borys, Z. Ya. (2018). Vypadok hostroho neiroboreliozu u khlopchyka shkilnoho viku [Case report of acute neuroborreliosis in a school-age boy]. Aktualna infektolohiia - Actual Infectology, 6, 4, 53-54. DOI: 0.22141/2312-413x.6.4.2018.142475 [in Ukrainian].

8. Norman, G.L., Antig, J.M., Bigaignon, G., \& Hogrefe, W.R. (1996). Serodiagnosis of Lyme borreliosis by Borrelia burgdorferi sensu stricto, B. garinii, and B. afzelii western blots (immunoblots). J. Clin. Microbiol., 34 (7), 1732-1738. DOI: 10.1128/JCM.34.7.1732-1738.1996.

9. Centers for disease control and prevention (2012). Reported cases of Lyme disease by year, United States, 2002-2011. Retrieved from: http://www.cdc.gov/lyme/ stats/chartstables/casesbyyear.html.

10. Andreichyn, M.A., Shkilna, M.I., \& Nykytiuk, S.O. (2017). Chastota vyiavlennia borelii i anaplazmy u klishchiv, vyluchenykh vid meshkantsiv Ternopilskoi oblasti [Frequency of detection of Borellia and anaplasma at the tick extracted from the residents of Ternopil region]. Epidemiolohichni ta klinichni uskladnennia infektsiinykh i parazytarnykh
72. Weber K. Jarish-Herxheimer-Reaktion bei erythema migrans-Krankheit / K. Weber // Hautarzt. - 1988. - Vol. 35 (11). - P. 588-590.

73. Singh Ls. K. Lyme Borreliosis: from infection to autoimmunity / Ls. K. Singh, J. Girschick // Clin. Microbiol. Infect. - 2004. - Vol. 10 (7). - P. 598-614.

74. Ljøstad U. The phenomenon of 'chronic Lyme'; an observational study / U. Ljøstad, A. Mygland // Eur. J. Neurol. - 2012. - Vol. 19 (8). - P. 1128-1135.

khvorob u suchasnykh umovakh - Epidemiological and clinical harmonization of infectious and parasitic diseases in modern conditions. Proceedings of the All-Ukrainian scientific-practical conference of infectious disease specialists and plenum of the All-Ukrainian Association of Infectious Diseases NGOs (pp. 9-11). Ternopil: Ukrmedknyha [in Ukrainian].

11. Nykytyuk, S., \& Klymnyuk, S. (2021). Clinical and immunological status of children with lyme disease. Health Problems of Civilization. DOI: https://doi.org/10.5114/ hpc.2021.108379.

12. Yoon, E.C., Vail, E., Kleinman, G., Lento, P.A., Li, S., Wang, G., ..., \& Fallon, J.T. (2015). Lyme disease: a case report of a 17-year-old male with fatal Lyme carditis. Cardiovasc. Pathol., 24 (5), 317-321. DOI: 10.1016/j.carpath.2015.03.003.

13. Tsentr hromadskoho zdorovia Ukrainy [Center for Public Health of Ukraine]. MOZ (phc.org.ua). Retrieved from: https://phc.org.ua [in Ukrainian].

14. Steere, A.C. (2001). Lyme disease. N. Engl. J. Med., 345 (2), 115-125. DOI: 10.1056/nejm200107123450207.

15. Philip, S.S. (2013). Current medical diagnosis and treatment. Spirochetal Infections. New York: Mc-Graw-Hill. Retrieved from: http://www.accessmedicine.com.eres.library.manoa.hawaii.edu/content.aspx?aID=18802\&search Str=lyme+disease.

16. Caulfield, A.J., \& Pritt, B.S. (2015). Lyme disease coinfections in the United States. Clin. Lab. Med., 35 (4), 827-846.

17. Wilking, H. (2014). Trends in surveillance data of human Lyme borreliosis from six federal states in eastern Germany. Ticks Tick Borne Dis., 5 (3), 219-224.

18. Krause, P.J., McKay, K., Thompson, C.A., Sikand, V.K., Lentz, R., Lepore, T., ..., \& Spielman, A. (2002). Disease-specific diagnosis of co-infecting tick-borne zoonoses: Babesiosis, human granulocytic ehrlichiosis, and Lyme disease. Clin. Infect. Dis., 34 (9), 11841191. DOI: 10.1086/339813.

19. Krause, P.J., Fish, D., Narasimhan, S., \& Barbour, A.G. (2015). Borrelia miyamatoi infection in nature and in humans. Clin. Microbiol. Infect., 21 (17), 631-639. DOI: 10.1016/j.cmi.2015.02.006.

20. Cutler, S.J., Rudenko, N., Golovchenko, M., Cramaro, W.J., Kirpach, J., Savic, S., Christova, I., \& Amaro, A. (2017). Diagnosing borreliosis. Vector-Borne Zoonotic Dis., 17, 2-11. DOI: $10.1089 / v b z .2016 .1962$.

21. Nyman, D., \& Wahlberg, P. (2017). Lyme borreliosis (LB). EBM Guidelines. Retrieved from: https://www.ebmguidelines.com/dtk/ebmaz/avaa?p_artikkeli=ebm00031.

22. Steer, A.C. (2010). Lyme borreliosis. Harrison's infectious diseases. Casper, D.L., \& Fauci, A.S. eds. 17th edn. 


\section{Огляди літератури, оригінальні дослідження, погляд на проблему, випадок з практики, короткі повідомлення}

New York: the McGraw-Hill Companies.

23. Murina, E.A., Goleva, O.V., Osipova, Z.A., \& Mukomolova, A.L. (2018). Problemy serologicheskoy diagnostiki iksodovogo kleshchevogo borrelioza u detey [The problems of serologicl diagnostics of tick-borne borreliosis in children]. Laboratoriya LPU. Spetsvypusk - LPU laboratory. Special Issue, 13, 38-40. Retrieved from: http://www.poliklin.ru/imagearticle/20184(1)/38.pdf [in Russian].

24. Stanek, G., Wormser, G.P., Gray, J., \& Strle, F. (2012). Lyme borreliosis. Lancet, 379, 461-473. DOI: 10.1016/S01406736(11)60103-7.

25. Bartosik, K., Kubrak, T., Olszewski, T., Jung, M., \& Buczek, A. (2008). Prevention of tick bites and protection against tick-borne diseases in south-eastern Poland. Ann. Agric. Environ. Med., 15 (2), 181-185.

26. Perelik osoblyvo nebezpechnykh, nebezpechnykh infektsiinykh ta parazytarnykh khvorob liudyny ta nosiiv zbudnykiv tsykh khvorob [List of especially dangerous, dangerous infectious and parasitic human diseases and carriers of pathogens of these diseases]. Nakaz Ministerstva okhorony zdorovia Ukrainy vid 19.07.1995 r. № 133 Order of the Ministry of Health of Ukraine dated 19.07.1995. No. 133 [in Ukrainian].

27. (2017). Centers for Disease Control and Prevention. Lyme disease (Borrelia burgdorferi): 2017 case definition. Retrieved from: https://wwwn.cdc.gov/nndss/conditions/lyme-disease/case-definition/2017.

28. Stanek, G., Fingerle, V., Hunfeld, K.P., Jaulhac, B., Kaiser, R., Krause, A., ..., \& Gray, J. (2011). Lyme borreliosis: clinical case definitions for diagnosis and management in Europe. Clin. Microbiol. Infect., 17 (1), 69-79. DOI: 10.1111/ j.1469-0691.2010.03175.x.

29. Kramarov, S.O., \& Holubovska, O.A. (2019). Infektsiini khvoroby: entsyklopedychnyi dovidnyk [Infectious diseases: encyclopedic reference book]. 2nd edn., revised and suppl. Kyiv: TOV "Harmoniia" 712 p. [in Ukrainian].

30. Sigal, L.H. (1995). Early disseminated Lyme disease: cardiac manifestations. Am. J. Med., 98 (4A), 25S-28S, discussion 28S-29S. DOI: 10.1016/S0002-9343(99)80041-2.

31. Karavayev, V.S., Oleynikova, Ye.S., Azayev, M.Sh., \& Beklemishev, A.B. (2016). Immunokhimicheskiy analiz rekombinantnogokhimernogo polipeptida OspC [gar+afz] izolyatov b. garini i b. afzelli [Immunochemical analysis of the recombinant chimeric OspC polypeptide [gar + afz] b. garini and b. afzelli]. Zhurnal mikrobiologii, epidemiologii $i$ immunobiologii - J. Microbiol., Epidemiol. Immunobiol., 3, 37-44 [in Russian].

32. Smiyan, S., Galaychuk, I., Zhulkevych, I., Nykolyuk, V., Komorovsky, R., Gusak, S., Bilozetsky, I. (2019). Sjögren's syndrome and lymphadenopathy unraveling the diagnosis of Lyme diseas. Reumatologia, 57 (1), 59-62. Retrieved from: https://doi.org/10.5114/reum.2019.83242.

33. Dahl, V., Wisell, K.T., Giske, C.G., Tegnell, A., \& Wallensten, A. (2019). Lyme neuroborreliosis epidemiology in Sweden 2010 to 2014: clinical microbiology laboratories are a better data source than the hospital discharge diagnosis register separator commenting unavailable. Euro. Surveill, 24 (20). DOI: 10.2807/1560-7917.ES.2019.24.20.1800453.

34. [Electronic resource]. Retrieved from: https:// guidelines.moz.gov.ua/documents/2959.

35. Bacon, R.M., Kugeler, K.J., \& Mead, P.S. (2008). Centers for Disease Control and Prevention (CDC) Surveil- lance for Lyme disease-United States, 1992-2006. MMWR Surveill Summ., 57 (10), 1-9.

36. Nyman, D., \& Wahlberg, P. (2017). Lyme borreliosis (LB) EBM Guidelines. Retrieved from: https://www.ebmguidelines.com/dtk/ebmaz/avaa?p_artikkeli=ebm00031.

37. Steere, A.C., McHugh, G., Suarez, C., Hoitt, J., Damle, N., \& Sikand, V.K. (2003). Prospective study of coinfection in patients with erythema migrans. Clin. Infect. Dis., 36 (8), 1078-1081. DOI: 10.1086/368187.

38. Weber, K. (2001). Aspects of Lyme borreliosis in Europe. Eur. J. Clin. Microbiol. Infect. Dis., 20 (1), 6-13. DOI: $10.1007 / \mathrm{s} 100960000412$.

39. (2019). Tsentralizovannaya informatsionnaya sistema po infektsionnym zabolevaniyam Yevropeyskogo regionarnogo byuro VOZ [Centralized Information System for Infectious Diseases of the WHO European Regional Bureau]. Retrieved from: http://www.euro.who.int/en/search? $q=$ lyme+disease+in+ukraine.

40. Karan, L., Makenov, M., Kolyasnikova, N., Stukolova, O., Toporkova, M., Olenkova, O., ..., \& Olenkova, O. (2018). Dynamics of spirochetemia and early PCR detection of Borrelia miyamotoi. Emerg. Infect. Dis., 24 (5), 860-867. DOI: 10.3201/eid2405.170829.

41. Klymniuk, S.I., Romaniuk, L.B., \& Shkilna, M.I. (2017). Suchasni uiavlennia pro hranulotsytarnyi anaplazmoz liudyny [Modern views about the granulocytic anaplasmosis of a man]. Infektsiini khvoroby - Infect. Dis., 3, 4-9. DOI: 10.11603/1681-2727.2017.3.8220.

42. Steere, A.C., Coburn J., \& Glickstein L. (2004). The emergence of Lyme disease. J. Clin. Invest., 113 (8), 10931101. DOI: $10.1172 / \mathrm{JCI} 21681$.

43. Penevskaya, N.A., Rudakov, N.V., Abramova, N.V., Rudakova, S.A., \& Kolomensky, A.P. (2009). Kliniko-epidemiologicheskiy analiz rezultatov vyyavleniya antitel $k$ razlichnym vidam rikketsiy u bolnykh s podozreniyem na kleshchevuyu neyroinfektsiyu v severnykh rayonakh Omskoy oblasti [Clinical and epidemiological analysis of the results of detecting antibodies to various types of rickettsia in patients with suspected tick-borne neuroinfection in the northern regions of the Omsk region]. Sibirskiy meditsinskiy zhurnal - Siberian Med. J., 8, 48-53 [in Russian].

44. Logigian, E.L., Kaplan, R.F., \& Steere, A.C. (1990). Neurologic manifestations of Lyme disease. N. Engl. J. Med.,323(21),1438.DOI:10.1056/NEJM199011223232102.

45. Nau, R., Christen, H.J., \& Eiffert, H. (2009). Lyme disease: current state of knowledge. Dtsch. Arztebl. Int., 106 (95), 72-81. DOI: 10.3238/arztebl.2009.0072.

46. Drakina, S.A., Anisko, L.A., Shcherba, V.V., Samoylova, T.I., \& Krasko, A.G (2018). Mikst-infektsiya: kleshchevoy entsefalit i granulotsitarniy anaplazmoz cheloveka [Mixed infection: tick-borne encephalitis and human granulocytic anaplasmosis]. Klinicheskaya infektologiya $i$ parazitologiya - Clinical Infectology and Parasitology, 1, 21 26 [in Russian].

47. Halperin, J.J. (2010). Nervous system Lyme disease. J. R. Coll. Physicians Edinb., 40 (3), 248-255. DOI: 10.4997/JRCPE.2010.314.

48. Södermark, L., Sigurdsson, V., Näs, W., Wall, P., \& Trollfors, B. (2017). Neuroborreliosis in Swedish children: A Population-based study on incidence and clinical characteristics. Pediatr. Infect. Dis. J., 36 (11), 1052-1056. DOI: 10.1097/INF.0000000000001653. 
Огляди літератури, оригінальні дослідження, погляд на проблему, випадок з практики, короткі повідомлення

49. Mygland, A., Ljøstad, U., Fingerle, V., Rupprecht, T., Schmutzhard, E., \& Steiner, I. (2010). EFNS guidelines on the diagnosis and managementof European Lyme neuroborreliosis. Eur. J. Neurology, 17, 8-16. DOI: 10.1111/j.14681331.2009.02862.x.

50. Remiker, A., Haslam, D., \& Kalfa, T.A. (2020). A painless erythematous swelling of the external ear as a manifestation of Lyme disease. J. Med. Case Rep., 14 (48), 48. DOI: 10.1186/s13256-020-02377-x.

51. Dressler, F., Ackermann, R., \& Steere, A.C. (1994). Antibody responses to the three genomic groups of Borrelia burgdorferi in European Lyme borreliosis. J. Infect. Dis., 169 (2), 313-318. DOI: 10.1093/infdis/169.2.313.

52. Henningsson, A.J., Christiansson, M., Tjernberg, I., \& Löfgren, S. (2014). Laboratory diagnosis of Lyme neuroborreliosis: acomparison of three CSF anti-Borrelia antibody assays. Eur. J. Clin. Microbial Infect. Dis., 33 (5), 797803. DOI: 10.1007/s10096-013-2014-6.

53. Galaychuk, I.Y., Zhulkevych, I.V., Smiyan, S.I., Nykolyuk, V.D., \& Komorovsky, R.R. (2019). Boreliozna limfadenopatiia u praktytsi onkoloha (klinichni sposterezhennia) [Borrelious lymphadenopathy in oncology practice (clinical observations)]. Onkolohiia - Oncology, 21 (3), 250-253. DOI: 10.32471/oncology.2663-7928.t-21-3-2019-7896 [in Ukrainian].

54. Lobzin, Yu.V., Rakhmanova, A.G., \& Antonov, V.S. (2000). Rekomendatsii dlya vrachey [Recommendations for doctors]. Saint Petersburg [in Russian].

55. Volokha, A.P. (2016). Khvoroba Laima (klishchovyi borelioz). Infektsiini khvoroby u ditei [Lyme disease (tickborne borreliosis). Infectious diseases in children]. Chernyshova L.I., ed. Kyiv: VSV «Medytsyna» [in Ukrainian].

56. Steere, A.C., Malawista, S.E., Snydman, D.R., Shope, R.E., Andiman, W.A., Ross, M.R., \& Steele, F.M. (1977). Lyme arthritis: an epidemic of oligoarticular arthritis in children and adults in three Connecticut communities. Arthritis Rheum., 20 (1), 7-17. DOI: 10.1002/art.1780200102.

57. Steere, A.C., \& Angelis, S.M. (2006). Therapy for Lyme arthritis: strategies for the treatment of antibioticrefractory arthritis. Arthritis Rheum., 54 (10), 3079-3086. DOI: 10.1002/art.22131.

58. Stanek, G., Wormser, G.P., Gray, J., \& Strle, F. (2012). Lyme borreliosis. Lancet, 379 (9814), 461-473. DOI: 10.1016/ S0140-6736(11)60103-7.

59. Arvikar, S.L., \& Steere, A.C. (2015). Diagnosis and treatment of Lyme arthritis. Infect. Dis. Clin. North. Am., 29 (2), 269-280. DOI: 10.1016/j.idc.2015.02.004

60. Wormser, G.P., Brisson, D., \& Liveris, D. (2008). Borrelia burgdorferi genotype predicts the capacity for hematogenous dissemination during early lyme disease. J. Infect. Dis., 198 (9), 1358-1364. DOI: 10.1086/592279.

61. Caforio, A.L., Pankuweit, S., Arbustini, E., Basso, C., Gimeno-Blanes, J., Felix, S.B., ..., \& Elliott, P.M. (2013). Current state of knowledge on aetiology, diagnosis, management, and therapy of myocarditis: a position statement of the European Society of Cardiology Working Group on Myocardial and Pericardial Disease. Eur. Heart J., 34 (33), 26342648. DOI: 10.1093/eurheart/eht210

62. Nelson, C.A., Saha, S., Kugeler, K.J., Delorey, M.J., Shankar, M.B., Hinckley, A.F., \& Mead, P.S. (2015). Incidence of clinician-diagnosed Lyme disease, United States, 20052010. Emerging Infect. Dis., 21 (9), 1625-1631. DOI: $10.3201 /$ eid2109.150417.

63. Yeung, C., \& Baranchuk, A. (2019). Diagnosis and treatment of Lyme carditis: JACC review topic of the week. J. Am. Coll. Cardiol., 73 (6), 717-726. DOI: 10.1016/j. jacc.2018.11.035.

64. Torbey, E., Nalluri, N., Karam, B., Agarwal, V., \& Bekheit, S. (2015). Conduction riddles of Lyme carditis: a case series. J. Innov. Card. Rhythm. Manag., 6 (5), 20042007. DOI: 10.7759/cureus.5554.

65. Nassar-Sheikh Rashid, A., Boele van Hensbroek, M., Kolader, M., Hovius, J.W., \& Pajkrt, D. (2018). Lyme borreliosis in children: a tertiary referral hospital-based retrospectiveanalysis. Pediatr. Infect. Dis. J., 37 (2), e45-e47. DOI: 10.1097/INF.0000000000001735.

66. Shah, S.S., Zaoutis, T.E., Turnquist, J., Hodinka, R.L., \& Coffin, S.E. (2005). Early differentiation of Lyme from enteroviral meningitis. Pediatr. Infect. Dis. J., 24 (6), 542-545. DOI: 10.1097/01.inf.0000164767.73746.6e.

67. Thompson, A.D., Cohn, K.A., Shah, S.S., Lyons, T., Welsh, E.J., Hines, E.M., \& Nigrovic, L.E. (2012). Treatment complications in children with Lyme meningitis. Pediatr. Infect. Dis. J., 31 (10), 1032-1035. DOI: 10.1097/ INF.0b013e31825eb3c7.

68. Cruickshank, M., O'Flynn, N., \& Faust, S.N. (2018). Lyme disease: summary of NICE guidance. Br. Med. J., 361, k1261. DOI: https://doi.org/10.1136/bmj.k1261.

69. Garro, A.C., Rutman, M.S., Simonsen, K., Jaeger, J.L., Chapin, K., \& Lockhart, G. (2011). Prevalence of Lyme meningitis in children with aseptic meningitis in a Lyme disease-endemic region. Pediatr. Infect. Dis. J., 30 (11), 990-992. DOI: 10.1097/INF.0b013e31822e8e68.

70. Peltomaa, M., Saxen, H., Seppälä, I., Viljanen, M., \& Pyykkö, I. (1998). Paediatric facial paralysis caused by Lyme borreliosis: a prospective and retrospective analysis. Scand. J.Infect.Dis.,30(3),269-275.DOI:10.1080/00365549850160927.

71. Nykytyuk, S., Boyarchuk, O., Klymnyuk, S., \& Levenets, S. (2020). The Jarisch-Herxheimer reaction associated with doxycycline in a patient with Lyme arthritis. Reumatologia, 58 (5). 335-338. DOI: 10.5114/reum.2020.99143.

72. Weber, K. (1988). Jarish-Herxheimer-Reaktion bei erythema migrans-Krankheit. Hautarzt, 35, 588-590.

73. Ljøstad, U., \& Mygland, Å. (2012). The phenomenon of 'chronic Lyme'; an observational study. Eur. J. Neurol., 19 (8), 1128-1135. DOI: 10.1111/j.1468-1331.2012.03691.x.

74. Ljøstad, U., \& Mygland, Å. (2012). The phenomenon of 'chronic Lyme'; an observational study. Eur. J. Neurol., 19 (8), 1128-1135. DOI: 10.1111/j.1468-1331.2012.03691.x. 
Огляди літератури, оригінальні дослідження, погляд на проблему, випадок з практики, короткі повідомлення

\section{CURRENT ISSUES OF LYME DISEASE IN CHILDREN}

@S. O. Nykytyuk, S. I. Klymnyuk

\section{Horbachevsky Ternopil National Medical University}

SUMMARY. Lyme disease has various clinical manifestations and should be ruled out in all patients with a tick bite. Lyme disease is caused by Borrelia burgdorferi senso lato, the causative agent of a heterogeneous group from which three genes are systematically associated with Lyme disease: B. burgdorferi senso stricto, B. afzelii and B. garinii and is an endemic disease in Ukraine.

Early clinical markers of Lyme borreliosis and other life-threatening prognostic factors, complications of borreliosis infection, are still at the beginning of active research by scientists.

Conclussions. Clinicians, including family physicians, rheumatologists, immunologists, and molecular cardiologists, should be involved in the development of new criteria, including the clinical picture and laboratory results.

KEY WORDS: children; Lyme borreliosis; diagnosis; treatment, ticks. 